hormone deficiency in 6 with multiple tropic hormone deficiencies in $4 / 6$. In 3 of 4 patients, in whom a PEG was performed, absence of septum pellucidum, thin optic nerves and chiasm, abnormal fornices, irregular lamina terminalis, and an abnormally shaped 3rd ventricle with small inferior pointing diverticulum from the optic recess were demonstrable. The sella turcica and suprasellar cistern were normal. EEG dysrhythmias were noted in 2 of 4 patients tested; I.Q. was normal or mildly subnormal in 6 . No evidence of ocular abnormalities or dwarfism was noted in the parents or sibs of the 6 patients. Hence, sporadic hypopituitary dwarfism is not uncommonly associated with a characteristic congenital malformation of the prosencephalon. The hypopituitarism is ascribable to a diencephalic defect which results in deficiency of hypothalamic hypophysiotropic factors and in some cases vasopressin.

177 Two Types of Congenital Cysts of the Posterior Fossa: A Comparison of Their Clinical and Pathological Characteristics and Their Embryogenesis. JEROME S. Haller, Samuel M.Wolpert and Edward F.RABE, Tufts Univ. Sch. of Med., New England Med. Center Hosps., Depts. of Ped., Neurol., and Radiol., Boston, Mass.

Two types of cystic lesions can occur in the posterior fossa of infants and children. In one type there is a cystic dilatation of the 4 th ventricle known as the Dandy-Walker (D-W) syndrome, and in the second type, a cyst or cysts overlie the cerebellum. This is referred to as a posterior fossa extra-axial cyst (PFEAC). These two entities may be differentiated clinically as will be illustrated by presentation of the findings in 2 infants with PFEAC and 2 with D-W syndrome. The pattern of skull transillumination is distinctive for each entity, although the differences are subtle, and can enable the clinician to suspect the correct diagnosis immediately. Arteriographic and air contrast findings show similar abnormalities in the supratentorial region in both conditions but distinctive differences are present in the infratentorial region. The histology of the cyst wall in PFEAC differs from that in $D$-W syndrome. Inferences drawn from a comparison of the arteriographic and histologic findings in these 4 cases with the appearance of certain brain structures at different stages of human embryogenesis indicate that both conditions are congenital abnormalities occurring before the 3rd fetal month but affecting the leptomeninges in one instance (PFEAC) and the cerebellar anlage in the other (D-W syndrome).

178 Quantitative RISA Subarachnoid to Plasma Transport and Subarachnoid Perfusion Tests in Children with Progressive Macrocephaly and Suspected Hydrocephalus. Thomas H. RockeI and EDward F. Rabe, Tufts Univ. Sch. of Med., New England Med. Center Hosps., Dept. of Ped. and Neurol., Boston, Mass.

A measure of the adequacy of lumbar subarachnoid to plasma CSF transport is obtained by determining quantitatively the percent of $12 / \mathrm{I}$ RISA in the plasma $24 \mathrm{~h}$ after its lumbar subarachnoid injection. This was done in 35 infants and children ranging in age from 5 weeks to 14 years. The ability of the CSF circulation to dispose of normal saline perfused into the lumbar subarachnoid space at a rate of $0.76 \mathrm{ml} / \mathrm{min}$ for $30-60$ min was determined by CSF pressure measurements at 5-min intervals during the perfusion of a sedated patient. This was done also on 17 of the 35 patients. Patients with normal external CSF circulation transported $38.5 \pm 10.2 \%$ (2 S.D.) of the injected RISA; patients with communicating hydrocephalus, 16.1$25.4 \%$; those with obstructive hydrocephalus, 31.5 $45.8 \%$; and macrocephalic achondroplastic dwarfs, 29.9-53.1\%. The pattern of perfusion test CSF pressures could be divided into 3 distinct forms: normal, uncompensated abnormal and partially compensated abnormal. In every instance save one, the results of the two tests on the same patient agreed. This patient with hydrocephalus and porencephaly had a normal RISA transport test but an abnormal uncompensated perfusion pattern. From these data we conclude, (1) that both tests are needed to evaluate the adequacy of the external CSF circulation, and (2) the external circulation can be normal when the internal circulation (ventricles to cisterna magna) is obstructed.

179 Failure of Exchange Transfusion to Prevent Minimal Cerebral Damage When Employed so as to Maintain Serum Bilirubin: Concentrations Below 18 and $20 \mathrm{mg} /$ $100 \mathrm{ml}$. Lois H.Johnson and Thomas R. Boggs, Dept. of Ped., Pennsylvania Hosp., Philadelphia, PA.

The occurrence of minor cerebral deficit in the absence of gross neurologic damage as a result of neonatal hyperbilirubinemia has been suspected for some time [DAy and Harnes, Pediatrics 00:000, 1954]. Recently ODELL (J.Pediat. 00: 000, 1970] has documented the presence of such damage by means of psychometric and neurologic evaluations at age 5 to 6 years in a group of jaundiced infants treated with exchange transfusion. Damage was found to correlate with degree of saturation of the serum proteins with bilirubin (as measured by his salicylate saturation index). We are confirming these results in a similar study using our HABA technique (Program SPR 1966, Coleman, Jr. $50 \mathrm{~L}$ serum, cc $30 \times 10^{-5} \mathrm{HABA}, \mathrm{PO}_{4}$ buffer) as a measure of serum binding reserve.

Analysis of the first group of infants being recalled at age 4 years for detailed psychometric, speech and hearing and neurologic examinations suggests that jaundiced infants whose HABA binding levels fall below $50 \%$ are likely to suffer some degree of measurable damage which infants whose binding levels remain above this level will escape (Chi square $=6.04$, $\mathrm{p}=0.014, \mathrm{n}=41$ ). Correlation of damage with bilirubin/albumin molar ratio was good. As in the study of ODELL, correlation with serum bilirubin concentration was poor.

The data clearly indicate that if minimal as well as major cerebral damage as a consequence of neonatal jaundice is to be prevented more exchange transfusions will have to be done or some alternative or additional form of therapy will have to be used. Phototherapy in conjunction with exchange transfusion gives promise of providing increased protection without increased therapeutic risk. Its ability to do so should be subjected to the scrutiny of long-term follow up studies.

180 Effects of Hyperoxia on the Nucleic Acid Contents of Developing Brain. Gilman D. Grave, Gharles KenNedy and Louis Sokoloff, Lab. of Cerebral Metabolism, Nat. Inst. Mental Health, Bethesda, MD.

Prolonged exposure of the newborn to elevated concentrations of oxygen may initiate pathologic changes in the retina, but, except for inhibition of capillary 
growth, no abnormalities have been described in brain. Ambient hyperoxia has been reported to inhibit nucleic acid synthesis in mammalian tissue cultures. The present studies suggest that hyperoxia may have similar effects in the developing brain in vivo. Newborn puppies were bottle-raised in $80 \%$ oxygen; weightmatched littermates were raised similarly in air. Over a nine-day period the mean weight gain was the same in both groups. Three days after termination of the oxygen exposure cerebral cortex and white matter were analyzed for DNA and RNA contents. The results obtained in nine pairs of animals were as follows:

Brain nucleic acid $\mathrm{P}_{\mathrm{i}}$ concentration in $\mathrm{mg} \mathrm{P} / 100 \mathrm{~g}$ wet weight, mean \pm S.E.M.

\begin{tabular}{lrrc}
\hline & $\begin{array}{c}\text { Oxygen- } \\
\text { exposed }\end{array}$ & Control & $\begin{array}{c}\mathrm{p} \\
\text { value }\end{array}$ \\
\hline DNA, gray matter & $6.84 \pm 0.53$ & $7.48 \pm 0.57$ & $<0.01$ \\
RNA, gray matter & $11.82 \pm 0.66$ & $13.07 \pm 0.72$ & $<0.02$ \\
DNA, white matter & $6.35 \pm 0.30$ & $6.84 \pm 0.38$ & n.s. \\
RNA, white matter & $8.94 \pm 0.31$ & $9.88 \pm 0.42$ & $<0.02$ \\
\hline
\end{tabular}

No differences were found in histologic examinations of brain sections. These findings indicate that ambient hyperoxia may inhibit nucleic acid snythesis and cell proliferation in the developing dog brain.

181 Subacute Sclerosing Panencephalitis: A New Serological Test in the Diagnosis of the Disease. MrahaeL Katz, Volker ter Meulen, Larry Leonard and Hilary Koprowski, Wistar Inst., Philadelphia, Pa., Dept. of Ped., Univ. of Göttingen, Germany, and California Dept. of Public Health, Berkely, CA.

In patients suspected of subacute sclerosing panencephalitis (SSPE) high levels of measles antibody in the serum and CSF have been taken as a supporting diagnostic criterion for the disease. In the present study 14 sera from patients with SSPE, 3 early-measles-convalescent sera and 100 late-measles-convalescent sera were used for indirect immunofluorescent examination of tissue culture cells infected with wild measles virus and SSPE viruses. All 14 SSPE sera reacted with an antigen in the nuclei and cytoplasm of these infected cells, as did the 3 convalescent sera obtained 3 weeks after the onset of measles. However, no intranuclear fluorescence was detected when the 100 sera obtained
5 months or later after measles infection were used. Thus, SSPE sera derived from patients who had measles many months, or years, prior to the onset of their neurological disorder, behaved like early convalescent sera. This unusual characteristic can be applied as a diagnostic test for SSPE. (Supported by USPHS grant NS-6859; Grant MS 596-A-2 from the Nat. Multiple Sclerosis Soc.; DG grants Me270/4 and 270/6; and USPHS grant AI-1475.)

182 Characteristics of Measles Virus Isolated from $\mathrm{Pa}$ tients with SSPE. JOSEPH V. BAUBLIS and FRANCIS E. PAYNe, Univ. of Michigan Sch. of Med., Dept. of Ped., and Sch. of Pub. Health, Dept. of Epid., Ann Arbor, MI (introduced by A.V. Hennessy).

We have isolated measles virus from brain cell cultures derived from two children less than one year following immunization with a live virus vaccine. Recovery of 'mature' measles virus was accomplished only after prolonged serial subcultivation of cells from the patients, or cells from the patient cultured together with BS-C-1 cells or primary human kidney cells. Cell cultures before the 12th level of subcultivation showed the cytopathology and antigen associated with measles infection but produced no free virus. Isolation of measles virus from earlier passage levels of these cells was accomplished by intracerebral inoculation of newborn hamsters. Characterization studies completed to date have shown that the isolates are antigenically indistinguishable from other strains of measles virus. However, they have a distinctive CPE characterized by extensive syncytial formation and produce very large plaques under agar overlay. In continuous lines of monkey kidney cells they yield a low titer of virus, but grow poorly or not at all in continuous human cell lines. They are distinguishable from other strains of measles by their resistance to thermal inactivation at $40^{\circ} \mathrm{C}$. Both strains produce fatal, acute encephalitis in baby hamsters. The lack of information regarding viral markers and their stability for vaccine and wild strains of measles, has made it impossible to determine the origin of the isolates on the basis of laboratory studies. This situation stresses the need for continuing emphasis on epidemiologic surveillance of SSPE, as well as laboratory research on measles virus and its markers.

\section{INDEX OF ABSTRACTS}

(Numbers following entries refer to abstract number)

AbildgaArd, C.F. 115

absorption, jejunal 164

Aceto, T., Jr. 94

acid-base homeostasis 46 acid mucopolysaccharide 21 acidosis 135 acidosis, metabolic 64 ACTH 93

ADAms, M.S. 151

adenine nucleotide 116

$S$-adenosyl-L-methionine 75

adipose tissue 70

adrenal 87

adrenal, $\alpha$-inhibition 84

adrenal, function 91, 93 adrenal hyperplasia, congenital 89 adrenal hyperplasia, lipoid 77

adrenocorticosteroid 103 airway obstruction 168

Aksu, A. 175

alanine 64

alcoholism, maternal 152

aldosterone 80, 85

alkaline phosphatase 60

allergy 2

alpha $_{1}$-antitrypsin 165

AL-UBAidi, Y.Y. 49

amino acid metabolism 47, 71

aminoaciduria 175 aminoglutethimide 77

AmmanN, A.J. 3

ammonia 44,45

amniocentesis 20

Ances, I. G. 80

androgens 128

anemia, aplastic 130

anesthesia 139

Anthony, B.F. 95

Anthony, C. L., Jr. 147

antibiotics 144

antibodies 3, 4, 6

antibody 101,102

antielastase 165

antistaphylococcus 111 